\title{
Eco-toxic risk assessment and source distribution of trace metals in surface sediments of the coastal and in four rivers estuary of Sarawak
}

\author{
Ebenezer Aquisman Asare ${ }^{1,2^{*}} \mathbb{0}$, Zaini Assim ${ }^{1}$, Rafeah Wahi ${ }^{1}$ and Joseph Richmond Fianko ${ }^{2}$
}

\begin{abstract}
Background: Trace metals pollution in the coastal and estuarine sediment could harm water quality and aquatic organisms, leading to potential long-term health risks on the environment and humans. Thus, the purpose of this study was to conduct an assessment of selected trace metals in surface sediments of the coastal and in four rivers estuary in the Sarawak State of Malaysia to investigate their distribution, environmental risk, and potential source distribution.
\end{abstract}

Results: Average concentrations of trace metals in sediment increased in the following order: $\mathrm{Cd}^{<} \mathrm{As}^{<} \mathrm{Co}^{<} \mathrm{Cu}^{<} \mathrm{Ni}$ $<\mathrm{Cr}^{<} \mathrm{Zn}<\mathrm{Mn}^{<} \mathrm{Mg}$ < Fe. The enrichment, contamination, and geo-accumulation index results showed that surface sediments were polluted with $\mathrm{Zn}$ and $\mathrm{Mg}$. In contrast, the other metals (i.e., $\mathrm{As}, \mathrm{Fe}, \mathrm{Mn}, \mathrm{Ni}, \mathrm{Cr}, \mathrm{Cu}, \mathrm{Co}$, and $\mathrm{Cd}$ ) indicated background concentration to minor contamination. Generally, the pollution load index values showed that almost all the sampling sites were unpolluted with the selected trace metals. Sediment quality guidelines (SQGs) and risk indexes were employed to assess the ecotoxicological risk of trace metal contamination in the sediments. The results proved that studied trace metals are not likely to have a deleterious impact on bottom-dwelling organisms. Still, a further accumulation of trace metals such as $\mathrm{Zn}, \mathrm{Ni}$, and $\mathrm{Cr}$ with time may adversely affect bottom-dwelling organisms. The risk index results showed a low ecological risk to the study sites. The correlation analysis and principal component analysis indicated that nine studied trace metals have strong interrelationships, suggesting common pollution sources or similar geochemical characteristics.

Conclusions: The study highlights the need to make tremendous efforts to monitor and control trace metal pollution in the coastal and estuarine areas.

Keywords: Trace metals, Eco-toxic risk, Surface sediments, Pollutants, Bottom-dwelling organisms

\section{Background}

Trace metals are a pressing concern regarding pollution in aquatic ecosystems because of their persistence, bioaccumulation, environmental toxicity, etc. [1-3]. Aquatic bodies, for example, reservoirs [4], rivers [5, 6],

\footnotetext{
*Correspondence: aquisman1989@gmail.com

${ }^{1}$ Department of Chemistry, Faculty of Resource Science and Technology,

Universiti Malaysia Sarawak, 94300 Kota Samarahan, Sarawak, Malaysia

Full list of author information is available at the end of the article
}

estuaries and coastal [7, 8], wetlands [9], and lakes [10], receive trace metals in inadequately treated or untreated wastewater from agricultural, domestic, and industrial sources. As an essential constituent in riverine and estuarine environments, sediments are a source and a sink of trace metals $[11,12]$. Trace metals entering rivers and estuaries rapidly deposit into the sediment and are much more concentrated than in the water body of riverine, estuarine, or coastal systems $[13,14]$. When there is an alteration of the hydrological or the physicochemical 
conditions, trace metals in the sediment may resuspend or desorb to result in secondary pollution in the water body $[15,16]$. Trace metals accumulation in the sediment directly influences benthic organisms. Trace metals in sediment also affect many other organisms via the food chain and threaten the comfort of the aquatic environment. Thus, it is necessary to evaluate and appreciate the accumulation and distribution of trace metals in sediment.

Rambungan, Sibu, Salak, and Santubong Rivers are key rivers in the Sarawak state of Malaysia. They flow through the Kuching city and support many less densely populated towns, offering services to both agriculture and industry. Over the past few decades, there have been trace metals pollution in riverine, estuarine, and coastal sediment of the Sarawak state of Malaysia because of the wastewater discharge from agricultural, metallurgical, and mining industries carrying trace metals. Even though many researchers have studied trace metals pollution in the Rambungan, Sibu, Salak, and Santubong Rivers and their associate estuary $[17,18]$; a systematic study is still lacking to correlate the sediment with trace metals distribution, characteristics, risk assessment, likely sources, and their effect on the aquatic environment.

Geochemical indices used for ecological risk assessment of trace elements in surface sediments comprised of computation of enrichment factor (EF), contamination factor (CF), geo-accumulation index (Igeo), pollution load index (PLI) [19-21], potential ecological risk indices [22], and excess regression analysis $[20,23]$. Analyses of trace metals in river sediments have been used considerably for the essence of pollution monitoring $[19,24,25]$. A handful of these studies focused on the paths of imparting trace metals content in sediments without evaluating their ecotoxicological risks $[17,18]$. Therefore, this study aimed to determine ten trace metals (i.e., $\mathrm{Zn}, \mathrm{As}, \mathrm{Fe}, \mathrm{Mg}$, $\mathrm{Mn}, \mathrm{Ni}, \mathrm{Cr}, \mathrm{Cu}, \mathrm{Co}$, and $\mathrm{Cd}$ ) in surface sediments of the coastal and in four rivers estuary of the Kuching Division of Sarawak. Also, using the geochemical indices to evaluate the contribution of anthropogenic activities carrying trace metals into estuary and coastal sediment. Determining potential risks linked with trace metal toxicity using sediment quality guidelines and ecotoxicological risk index. Finally, ascertaining the source distribution of trace metals using statistical tools such as Pearson's coefficient correlation and principal component analysis.

\section{Methods}

\subsection{Description of the study area}

The field studies and sampling were conducted in the coastal and in four rivers (i.e., Santubong, Salak, Sibu, and Rambungan) estuary in the Kuching Division of Sarawak in the North-Western portion of Borneo Island,
Malaysia. The study area has a tropical rainforest climate, moderately hot yet very humid once in a while, and receives considerable rainfall. The mean annual precipitation is approximately $4200 \mathrm{~mm}$. The study area receives an average of 247 rainy days per year with an average of $6 \mathrm{~h}$ of sunshine and a mean of $3.7 \mathrm{~h}$ per day during January. North-East Monsoon months of November to February is the wettest time whiles June to August is considered the driest months. The temperature of the study area range between 19 to $36^{\circ} \mathrm{C}$ with a mean temperature of roughly $23{ }^{\circ} \mathrm{C}$ in the early hours of the morning and rises to approximately $33^{\circ} \mathrm{C}$ in the course of mid-afternoon and can reach $42{ }^{\circ} \mathrm{C}$ in the dry season. Figure 1 shows the sampling locations of the coastal and four rivers estuary.

\subsection{Sediment sampling and treatment}

The field studies and sample collection were conducted according to the procedure outlined by Gao [26] from September to October 2020. The coordinates for each sampling site were determined using a portable Global Positioning System (GPS), Garmin etrex (Table 1). Sixteen surface sediments were collected from sampling sites. Samples were collected at each sampling site at approximately $5.0 \mathrm{~cm}$ depth using a Wildco grab sampler. To minimize contamination, the grab sampler was disinfected using biodegradable detergent and rinsed with deionized water before and after each use. Sediments were placed in cleaned polyethylene containers and kept in the cooler box at a temperature of $5{ }^{\circ} \mathrm{C}$ during transportation. In the laboratory, samples were air-dried in a well-ventilated area for a week. The bulky materials such as stones and unwanted materials were removed from the sediments using stainless-steel forceps and homogenized. The dried sediment samples were pulverized into fine particles using a mortar and a pestle. Pulverized sediments were then sieved using a $55 \mu \mathrm{m}$ mesh size sieve to obtain powdered sediments which then placed in cleaned polyethylene containers. The samples were kept in a refrigerator for further analysis [27].

\subsection{Sediment extraction and analysis}

The procedure used to analyze sediment absolute trace metal contents is acid digestion adapted by Hossner [28]. A powdered sample of $0.5 \mathrm{~g}$ was placed in a crucible. About $3 \mathrm{~mL}$ of $\mathrm{H}_{2} \mathrm{SO}_{4}$ (95\%) and $4 \mathrm{~mL}$ of $\mathrm{HCl}(96 \%)$ were added to the crucible contents. The contents of the crucibles were then placed in an oven Memmert model $30-70$ (UN 30) at $115{ }^{\circ} \mathrm{C}$ for $20 \mathrm{~h}$ to break down all organic materials and the weight was recorded. The sediment samples were reheated at $500{ }^{\circ} \mathrm{C}$ for $3 \mathrm{~h} 30 \mathrm{~min}$ in a muffle furnace (Model Ney Vulcan D - 550 series) and the weights were recorded. $2.0 \mathrm{~mL}$ of distilled water and 


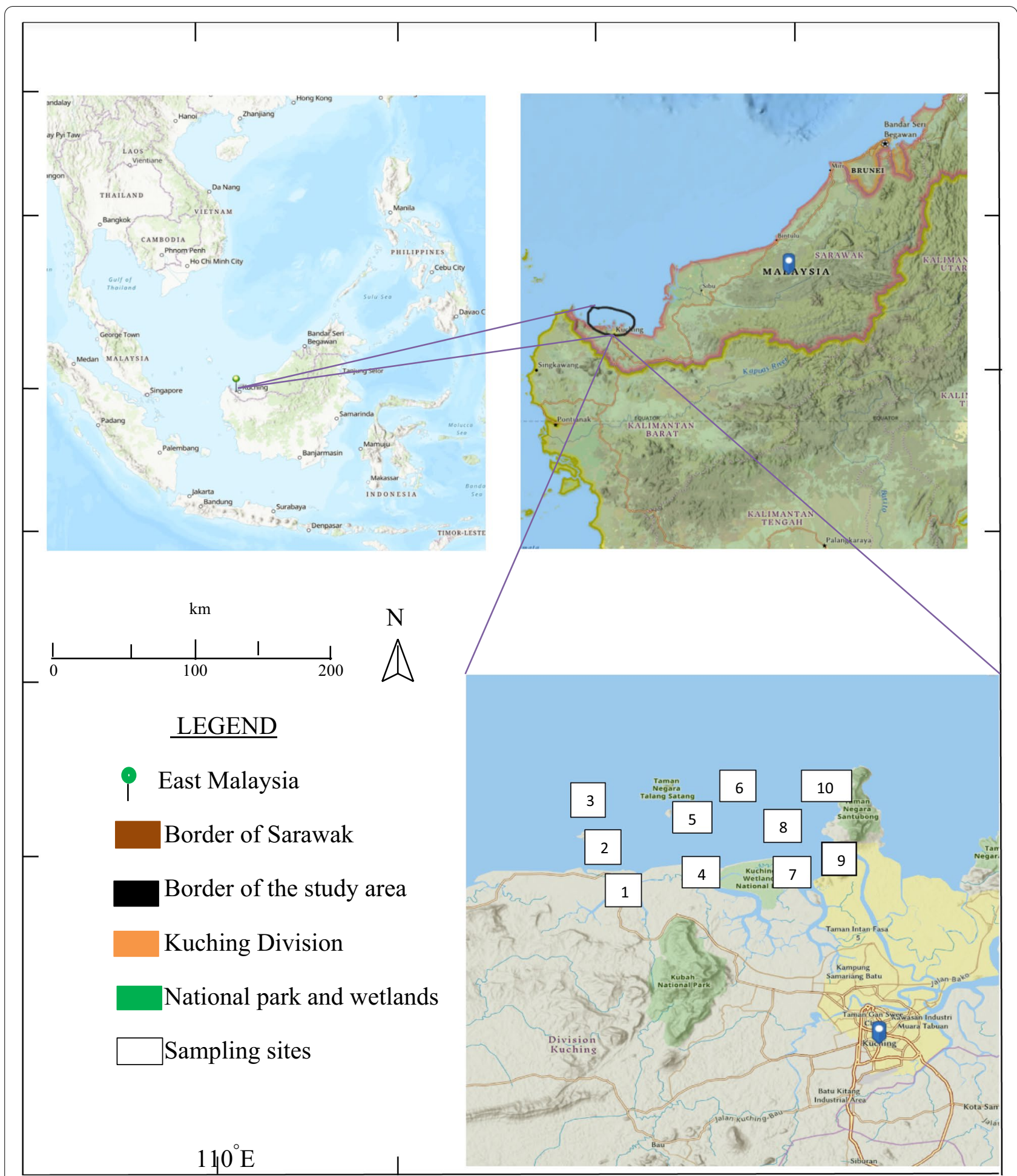

Fig. 1 Map of study area showing 10 sampling sites; adapted from Asare et al. [7]. Note: On the map, the sampling site codes were labelled numerically for easy identification of sampling position but the actual naming of each sampling site is attached with CZ for example sample site 1 denotes CZ1 
Table 1 Coordinates of sampling locations

\begin{tabular}{lll}
\hline Sample site code & Locality & Coordinates \\
\hline CZ1(1),(2) & Rambungan River Estuary & $\mathrm{N} 01^{\circ} 41^{\prime} 37.7^{\prime \prime} E 110^{\circ} 08^{\prime} 24.5^{\prime \prime}$ \\
CZ2(1),(2) & Offshore of Batang Rambungan opposite small Satang Island & $\mathrm{N} 01^{\circ} 44^{\prime} 46.8^{\prime \prime} E 110^{\circ} 08^{\prime} 45.4^{\prime \prime}$ \\
CZ3(1),(2) & $\mathrm{N} 01^{\circ} 46^{\prime} 22.6^{\prime \prime} E 110^{\circ} 08^{\prime} 37.8^{\prime \prime}$ \\
CZ4(1),(2) & Offshore of Batang Rambungan adjacent big Satang Island & $\mathrm{N} 01^{\circ} 44^{\prime} 46.8^{\prime \prime} E 110^{\circ} 08^{\prime} 45.4^{\prime \prime}$ \\
CZ5 & Sibu River Estuary & $\mathrm{N} 01^{\circ} 45^{\prime} 50.4^{\prime \prime} E 110^{\circ} 11^{\prime} 30.2^{\prime \prime}$ \\
CZ6 & Offshore of Telaga Air opposite to small Satang Island & $\mathrm{N} 01^{\circ} 47^{\prime} 23.5^{\prime \prime} E 110^{\circ} 10^{\prime} 39.7^{\prime \prime}$ \\
CZ7(1),(2) & $\mathrm{N} 01^{\circ} 40^{\prime} 41.1^{\prime \prime} E 110^{\circ} 16^{\prime} 59.2^{\prime \prime}$ \\
CZ8 & Offshore of Telaga Air adjacent big Satang Island & $\mathrm{N} 01^{\circ} 42^{\prime} 45.7^{\prime \prime} E 110^{\circ} 27^{\prime} 63.1^{\prime \prime}$ \\
CZ9(1),(2) & Salak River Estuary & $\mathrm{N} 01^{\circ} 44^{\prime} 49.6^{\prime \prime} E 110^{\circ} 29^{\prime} 72.3^{\prime \prime}$ \\
CZ10 & Santubong Bay & $\mathrm{N} 01^{\circ} 42^{\prime} 32.6^{\prime \prime} E 110^{\circ} 19^{\prime} 02.3^{\prime \prime}$ \\
\hline
\end{tabular}

$2.0 \mathrm{~mL}$ concentrated $\mathrm{HNO}_{3}$ were added to cool the samples and further heated to dryness on a hot plate (Model Favorit HS070V2 Serial 5434). $10 \mathrm{~mL}$ distilled water and $1.0 \mathrm{~mL}$ concentrated $\mathrm{HCl}$ were added to each crucible's content and stirred for $3 \mathrm{~min}$ for uniformity. The mixture was then filtered through Whatman No. 42 filter paper, and the content (filtrate) was top up with distilled water to $100 \mathrm{~mL}$. Trace metals concentrations were analyzed using an inductively coupled plasma optical emission spectrophotometer (ICP-OES).

\subsection{Quality assurance and control (QA/QC)}

To ensure the quality and efficiency of the instrumental outcomes; QA and QC techniques were established. It includes cleaning laboratory materials and apparatus using $15 \% \mathrm{H}_{2} \mathrm{SO}_{4}$, applying standard operating methods, analyzing blanks, and standard calibration and recovery of actual additions. Instrumental validation is a crucial analytical precondition of the multi-elemental analysis process. The procedure lays out a system for describing the efficiency of the instrument. In addition, it proves the performance abilities of the procedure being examined by ensuring that it is coherent with the used method [6]. The limit of detection (LOD) and limit of quantification (LOQ) were calculated for the ten trace metals after establishing the calibration curves and equation of ICPOES. The LOD and LOQ values were computed using the formulae adapted by [29]:

$$
\begin{aligned}
& \mathrm{LOD}=3.3 \times\left(\mathrm{S}^{\mathrm{d}} \mathrm{d}_{\text {blank }} / y\right) \\
& \mathrm{LOQ}=10 \times\left(\mathrm{S} . \mathrm{d}_{\text {blank }} / y\right)
\end{aligned}
$$

where S.d refers to mean standard deviation of blanks, and $y$ represents the sensitivity of the calibration curve [29]. Table 2 shows the properties' performance of the ICP-OES calibration equation.
Table 2 Characteristics performance of ICP-OES calibration equation

\begin{tabular}{llllll}
\hline Trace metal & \multicolumn{2}{l}{ Parameters } \\
\cline { 2 - 6 } & $\boldsymbol{R}^{\mathbf{2}}$ & Slope & Intercept & $\begin{array}{l}\text { LODs (mg/ } \\
\mathbf{k g})\end{array}$ & $\begin{array}{l}\text { LOQs (mg/ } \\
\mathbf{k g})\end{array}$ \\
\hline $\mathrm{Zn}$ & & & & 0.0404 & 0.1224 \\
$\mathrm{As}$ & 0.9880 & 0.0114 & 0.0012 & 0.0379 & 0.1149 \\
$\mathrm{Fe}$ & 0.9910 & 0.0136 & 0.0014 & 0.0106 & 0.0321 \\
$\mathrm{Mg}$ & 0.9720 & 0.0371 & 0.0206 & 0.0143 & 0.0143 \\
$\mathrm{Mn}$ & 0.9830 & 0.0131 & 0.0017 & 0.0143 & 0.1055 \\
$\mathrm{Ni}$ & 0.9910 & 0.0211 & 0.0043 & 0.0348 & 0.1000 \\
$\mathrm{Cr}$ & 0.9690 & 0.0431 & 0.0073 & 0.0429 & 0.1300 \\
$\mathrm{Cu}$ & 0.9950 & 0.0201 & 0.0134 & 0.0541 & 0.1639 \\
$\mathrm{Co}$ & 0.9990 & 0.0114 & 0.0036 & 0.0101 & 0.0306 \\
$\mathrm{Cd}$ & 0.9670 & 0.0633 & 0.0073 & 0.0132 & 0.0400 \\
\hline
\end{tabular}

$L O D$ limit of detection, $L O Q$ limit of quantification, $R^{2}$ variance

The method efficiency for the study was determined using recovery tests. Analyte for individual trace metal was used to spike the digestion sample solution. The spiked samples were analyzed, and the average concentration of trace metal after spiking was compared with the concentration of analyte trace metal before spiking. The recoveries were calculated as follows [6]:

$$
\text { Recovery }(\%)=\left(\text { Average Conc. }_{\text {spiked }} / \text { Analyte Conc. }\right) \times 100 \%
$$

The amount of trace metals concentrations was assessed according to the formula:

$$
\text { Final Conc. }(\mathrm{mg} / \mathrm{L})=\text { Conc. }_{\text {sediment }} \times \mathrm{DF} \times \mathrm{NV}(\mathrm{mL})
$$

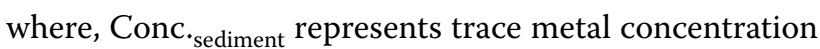
in sediment samples, DF denotes dilution factor, and NV is nominal volume. 
The percentage recoveries of the spiked samples analyzed varied from $89-104 \%$ (Table 3). The analyte level of approximately $1 \mathrm{mg} / \mathrm{kg}$ has been reported, and the acceptable recovery range is $90.0-110 \%[6,30,31]$. The obtained values in this current study were found to be within the acceptable recovery range. Hence, the analytical instrument is suitable to for analysis of selected trace metals.

\subsection{Environmental assessment of trace metals contamination \\ 2.5.1 Enrichment factor (EF)}

EF deals with estimating the anthropogenic impacts on the media, such as soil, sediments, and others. Iron $(\mathrm{Fe})$ is used as a normalization metal because the collected sediments from the study area were abundant in Fe. The EF can be calculated by Eq. 5 proposed by Muller [32].

$$
\mathrm{EF}=\left(\frac{\mathrm{Xn}}{\mathrm{Fe}}\right)_{\text {sample }} \div\left(\frac{\mathrm{Xn}}{\mathrm{Fe}}\right)_{\text {crust }}
$$

where, $(\mathrm{Xn} / \mathrm{Fe})_{\text {sample }}$ represents ratios of arithmetic average concentrations $(\mathrm{mg} / \mathrm{kg}$, dry $\mathrm{wt})$ of the target heavy metals; $(\mathrm{Xn} / \mathrm{Fe})_{\text {crust }}$ denotes $\mathrm{Fe}$ in the investigated sediments and continental earth crust according to Muller [32]. The classifications of trace metals enrichment and their environmental risk grades in soil/sediment are shown in Table 4.

\subsubsection{Contamination factor (CF)}

CF is applied to assess pollution in an aquatic ecosystem by a given toxic substance. Thus, it serves as a vital indicator of sediment contamination [33]. The CF was computed using Eq. 6 formulated by Hakanson [34] as:

Table 3 Method efficiency data for analysis of ten trace metals in spiked surface sediment samples

\begin{tabular}{llll}
\hline Trace metal & $\begin{array}{l}\text { Analyte Conc. } \\
\text { (mg/kg) }\end{array}$ & $\begin{array}{l}\text { Mean Conc. of a } \\
\text { spiked sample (mg/ } \\
\text { kg) }\end{array}$ & \% Recovery \\
\hline $\mathrm{Zn}$ & 1.00 & 0.98 & 98 \\
$\mathrm{As}$ & 3.00 & 2.75 & 92 \\
$\mathrm{Fe}$ & 2.00 & 2.08 & 104 \\
$\mathrm{Mg}$ & 1.00 & 1.01 & 101 \\
$\mathrm{Mn}$ & 2.00 & 1.95 & 98 \\
$\mathrm{Ni}$ & 2.00 & 1.78 & 89 \\
$\mathrm{Cr}$ & 2.00 & 1.98 & 99 \\
$\mathrm{Cu}$ & 1.00 & 0.97 & 97 \\
$\mathrm{Co}$ & 2.00 & 1.94 & 97 \\
$\mathrm{Cd}$ & 2.00 & 1.96 & 98 \\
\hline
\end{tabular}

$$
\mathrm{CF}=(\mathrm{Cm})_{\text {sample }} /(\mathrm{Cm})_{\text {background }}
$$

$\mathrm{Cm}_{\text {sample }}$ denotes the concentration of a given trace metal in sediment, and $(\mathrm{Cm})_{\text {background }}$ is the values of reference metal, which are the average shale values of each study metal for sedimentary rock [35]. The CF values are grouped into four groups as listed in Table 4.

\subsubsection{Geo-accumulation index (Igeo)}

Igeo makes it possible to determine pollution by comparing the present and pre-industrial concentrations of trace metals in the earth's crust [32]. The geo-accumulation index (Igeo) can be calculated using Eq. 7 [32]:

$$
\operatorname{Igeo}=\log _{2}\left(C_{n} / 1.5 * B_{n}\right)
$$

where, $C_{n}$ refers to the measured concentration of the trace elements in the sediment samples and Bn represents the geochemical background value in the earth's crust. The factor of 1.5 is introduced to reduce the impact of possible variations in the background values due to lithogenic variations (i.e., alteration during early chemical reactions within freshly deposited sediment) [36]. The interpretation of the Igeo values is summarised in Table 4.

\subsubsection{The pollution load index (PLI)}

PLI for each sampling site is derived as the $n$th root of $n$ number multiplied together by the values of the CF suggested by Tomilson et al., as shown by Eq. 8 [37].

$$
\text { PLI }=\left(C F_{1} * C F_{2} * C F_{3} * \ldots . C F_{n}\right)^{1 / n}
$$

where, $n$ represents the number of heavy metals. PLI index is ranked into several classes, as shown in Table 4.

\subsection{Ecological risk assessment}

\subsubsection{Sediment quality guidelines}

Sediment-quality guidelines (SQGs) were developed in Australia and New Zealand in 2000 to predict the adverse biological impacts caused by contaminated sediments [38]. The technique has been employed to determine the potential risk to aquatic organisms due to trace metal pollution in aquatic bodies [39]. The assessment is established by comparing the measured trace metal contents in sediment samples with the consensus-based threshold effect concentration (TEC), probable effect concentration (PEC) values, and midway values between the TEC and PEC (i.e., MEC) [40].

\subsubsection{Threshold effect concentration (TEC)}

TEC is a sediment contamination concentration at which a toxic response has begun to be observed in benthic organisms. Florida Department of Environmental Protection developed Eq. 9 to determine TEC based on the 
Table 4 Enriched factor (EF), contamination factor (CF), geo-accumulation index (Igeo) and pollution load index (PLI) range values and their environmental risk grades

\begin{tabular}{|c|c|c|c|}
\hline Index type & Value & Environmental risk grade & References \\
\hline \multicolumn{4}{|c|}{ Single Indices } \\
\hline \multirow[t]{8}{*}{$\mathrm{EF}$} & & & {$[32]$} \\
\hline & $0-1$ & Background concentration or no enrichment & \\
\hline & $1-3$ & Minor enrichment & \\
\hline & $3-5$ & Moderate enrichment & \\
\hline & $5-10$ & Moderately severe enrichment & \\
\hline & $10-25$ & Severe enrichment & \\
\hline & $25-50$ & Very severe enrichment & \\
\hline & $>50$ & Extremely serve enrichment & \\
\hline \multirow[t]{5}{*}{$\mathrm{CF}$} & & & {$[34]$} \\
\hline & $<1$ & Minimum contamination & \\
\hline & 1 to 3 & Moderate contamination & \\
\hline & 3 to 6 & Considerable contamination & \\
\hline & $>6$ & Very high contamination & \\
\hline \multirow[t]{8}{*}{ Igeo } & & & {$[32]$} \\
\hline & 0 & Uncontaminated or background concentration & \\
\hline & $0-1$ & Uncontaminated & \\
\hline & $1-2$ & Moderately contaminated to uncontaminated & \\
\hline & $2-3$ & Moderately contaminated & \\
\hline & $3-4$ & Moderately to highly contaminated & \\
\hline & $4-5$ & Highly contaminated & \\
\hline & $>5$ & Very highly contaminated & \\
\hline \multicolumn{4}{|c|}{ Integrated Index } \\
\hline \multirow[t]{4}{*}{ PLI } & & & {$[37]$} \\
\hline & 0 & Perfection & \\
\hline & 1 & Baseline & \\
\hline & $>1$ & Increasing contamination & \\
\hline
\end{tabular}

concentrations at which benthic organisms from aquatic ecosystems exhibited toxic responses in the laboratory [41].

$$
\mathrm{TEC}=\sqrt{ }(\mathrm{EDS}-\mathrm{L} * \mathrm{NEDS}-\mathrm{M})
$$

EDS-L represents the concentration at which $15 \%$ of benthos showed effects, and NEDS-L denotes concentration at which $50 \%$ of benthos showed no impact.

\subsubsection{Probable effect concentration (PEC)}

PEC is the concentration at which a large percentage of the benthic population shows a toxic response. PEC can be calculated using Eq. 10 as proposed by the Florida Department of Environmental Protection [41].

$$
\mathrm{PEC}=\sqrt{ }\left(\mathrm{EDS}-\mathrm{M}^{*} \mathrm{NEDS}-\mathrm{H}\right)
$$

EDS-M denotes concentration at which $50 \%$ of benthos showed effects, and NEDS-H indicates concentration at which $85 \%$ of benthos showed no impact.

\subsubsection{Median effect concentration (MEC)}

It is assumed that sediment contamination concentrations below TEC are acceptable and concentrations above the PEC are unacceptable. The region in between the TEC and PEC is called median effect concentration (MEC). The MEC values require further study and judgment to ascertain the likelihood of environmental consequences.

\subsubsection{Potential ecological risk index (RI)}

RI can be calculated using Eqs. 11-13 developed by Hakanson [34]. RI is widely used in evaluating the ecological risk of trace metals contamination in sediments [42]. Thus, RI is calculated using the formula:

$$
\begin{aligned}
& \mathrm{RI}=\sum \mathrm{E}_{\mathrm{i}} \\
& \mathrm{Ei}=\mathrm{TiFi}
\end{aligned}
$$




$$
\mathrm{Fi}=\mathrm{Ci} / \mathrm{Cb}
$$

where, RI is the sum of all risk factors in the sediment samples; $\mathrm{Ei}$ is the monomial potential ecological risk factor for individual factors; $\mathrm{Ti}$ is the metal toxic response factor and $\mathrm{Fi}$ is the metal contamination factor, $\mathrm{Ci}$ is the calculated concentration of trace metal in the sediment sample, and $\mathrm{Cb}$ refers to the value of the reference element [35]. Metal contamination factor (Fi), risk index classification, and their environmental risk intensity are highlighted in Table 5. The metal contamination factor data of eight out of the ten detected trace metals in the samples were available in literature [34]. Therefore, the potential ecological risk assessment of 8 trace metals was evaluated in this work.

\subsection{Statistical analysis}

SPSS 24.0 software (IBM Corp., Armonk, NY, USA) was used for basic descriptive statistical analysis of the sample data [43]. This provided the mean and standard deviation for the sampled trace metal concentrations. Bivariate analysis such as Pearson's correlation method was used to assess the correlations between trace metals and multivariate analysis such as principal component analysis (PCA) was applied to study the source distribution of the selected trace metals.

\section{Results}

\subsection{Distribution of trace metals in surface sediments}

Trace metal concentrations in surface sediments sampled from the coastal and in four rivers estuary are shown in Table 6. The concentration of detected zinc $(\mathrm{Zn})$ in the surface sediments varied from 57.02 to $155.05 \mathrm{mg} / \mathrm{kg}$ with an average concentration of $133.45 \mathrm{mg} / \mathrm{kg}$. It has been reported that $\mathrm{Zn}$ has high mobility, and dissolved $\mathrm{Zn}$ can potentially increase its biological availability in an aquatic ecosystem [19, 44-46]. Osullivan et al. suggested that $\mathrm{Zn}$ can readily adsorb and be scavenged by the hydroxides and oxides [47]. The high level of $\mathrm{Zn}$ concentration in the surface sediments could be attributed to the fuel station, vehicle emissions, and commercial discharges $[19,48]$.
The detected arsenic (As) concentration in the samples detected ranged from 3.02 to $6.88 \mathrm{mg} / \mathrm{kg}$ with a mean value of $5.13 \mathrm{mg} / \mathrm{kg}$ (Table 6). Arsenic primarily exists in the ecosystem because of natural processes (i.e., volcanic processes and weathering of rocks, etc.) and anthropogenic activities such as mining, industrial pollution, fertilizer, pesticides, and insecticides [27, 49]. The elevated concentration of As in the study area could be attributed to the excessive use of inorganic fertilizer and domestic sewage discharges [50].

The iron (Fe) concentrations in the analysed samples ranged from $10,142.25$ to $18,483.22 \mathrm{mg} / \mathrm{kg}$, with a mean value of $16,415.17 \mathrm{mg} / \mathrm{kg}$. In the current study, it was observed that Fe concentrations detected in all samples were higher compared to other trace metals. Apart from erosion, weathering, and some natural sources; the dominance of Fe in the surface sediments can be caused by large-scale anthropogenic processes including agricultural activities, solid waste, and urban-industrial discharges [51].

The occurrence of magnesium $(\mathrm{Mg})$ in sediments is either a solute in pore-fluids or an essential constituent in the formation of late-stage diagenetic chlorite and dolomite [52]. Mg concentration ranged from 7183.17 to $9561.75 \mathrm{mg} / \mathrm{kg}$ with an average value of $8597.46 \mathrm{mg} / \mathrm{kg}$ (Table 6). Mg is the second highest concentration following $\mathrm{Fe}$ in the collected surface sediments from the study area. The relatively high content of $\mathrm{Mg}$ may be attributed to $\mathrm{CaCO}_{3}$ sweating out from the sedimentary column or human activities such as industrial pollution, waste discharges, excessive pesticides, and fertilizer application [53].

Manganese $(\mathrm{Mn})$ concentration varied from 98.93 to $194.90 \mathrm{mg} / \mathrm{kg}$ with an average of $142.92 \mathrm{mg} / \mathrm{kg}$ (Table 6). The behavior of $\mathrm{Mn}$ in sediment is different compared to other trace metals and can be influenced by the existence of $\mathrm{MnO}_{2}$ in oxic surface sediments $[19,54]$. Loska and Wienchula suggested that Mn pollution results from deposition in the atmosphere and organic material emissions [55]. The nickel (Ni) concentration in the surface sediments ranged from 10.54 to $27.28 \mathrm{mg} / \mathrm{kg}$ with an average value of $20.18 \mathrm{mg} / \mathrm{kg}$ (Table 6). Loska and Wienchula

Table 5 Metal contamination factor (Fi) of the selected trace metals, classification and environmental risk intensity

\begin{tabular}{|c|c|c|c|c|c|c|c|c|}
\hline Trace metal & Co & $\mathrm{Cu}$ & $\mathrm{Ni}$ & $\mathrm{Cr}$ & $\mathrm{Zn}$ & $\mathrm{Mn}$ & Cd & As \\
\hline \multirow{2}{*}{$\begin{array}{l}\text { Metal contamination } \\
\text { factor }\end{array}$} & 5.0 & 5.0 & 5.0 & 2.0 & 1.0 & 1.0 & 30.0 & 10.0 \\
\hline & \multicolumn{4}{|c|}{ Risk Index Value } & \multicolumn{4}{|c|}{ Environmental Risk Categories } \\
\hline 1 & \multicolumn{4}{|c|}{$<150$} & \multicolumn{4}{|c|}{ Low ecological risk } \\
\hline 2 & \multicolumn{4}{|c|}{$\geq 150<300$} & \multicolumn{4}{|c|}{ Moderate ecological risk } \\
\hline 3 & \multicolumn{4}{|c|}{$\geq 300<600$} & \multicolumn{4}{|c|}{ Considerable ecological risk } \\
\hline 4 & \multicolumn{4}{|c|}{$\geq 600$} & \multicolumn{4}{|c|}{ Very high ecological risk } \\
\hline
\end{tabular}




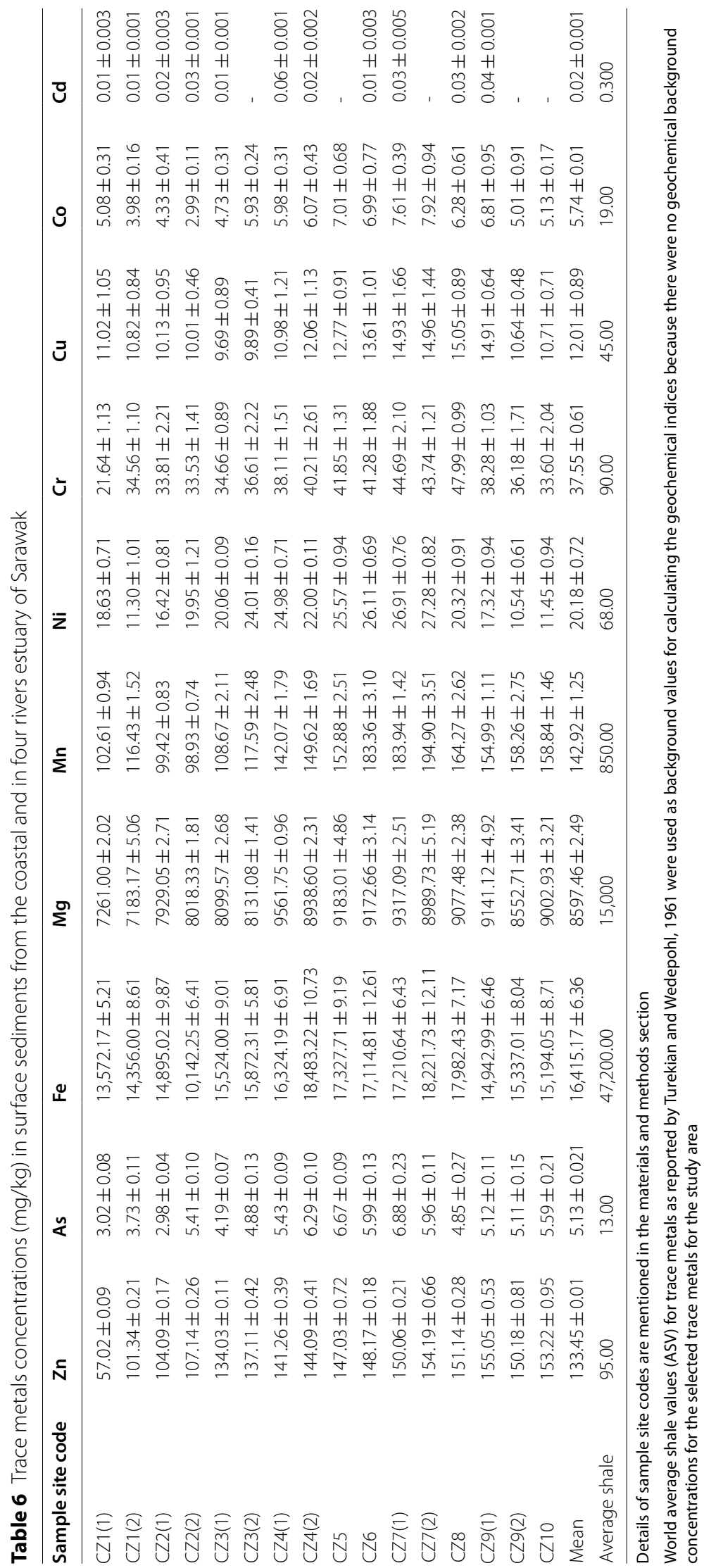


suggested that $\mathrm{Ni}$ is primarily available in the organically bound form in the soil, which under certain $\mathrm{pH}$ (acidic or neutral) conditions accelerate its movement and biological availability [55]. According to Anderson et al., the primary anthropogenic sources of Ni pollution are fuel combustion and agricultural wastes [56].

The concentration level of chromium $(\mathrm{Cr})$ varied from 21.64 to $47.99 \mathrm{mg} / \mathrm{kg}$ with an average concentration of $37.55 \mathrm{mg} / \mathrm{kg}$ (Table 6). Cr is regarded as low mobility trace metal, usually under moderately oxidizing and reducing conditions and nearly neutral $\mathrm{pH}$. Zarei et al. reported that $\mathrm{Cr}$ and its associate compounds are used in synthesizing steel and some alloys, pigment production, and chrome plating [57]. Thus, it can be deduced that the steel and iron industry and chrome plating are the primary sources of $\mathrm{Cr}$ in the study area. Copper $(\mathrm{Cu})$ concentration levels detected in all sampling sites varied from 9.69 to $15.05 \mathrm{mg} / \mathrm{kg}$ with a mean concentration of $12.01 \mathrm{mg} / \mathrm{kg}$ (Table 6). $\mathrm{Cu}$ as a mineral is of great importance for the proper growth and development of plants due to its constituent of different enzymes and proteins $[40,55] . \mathrm{Cu}$ is extensively applied in roofing, electrical wiring, and manufacturing pigments, piping, alloys, and cooking utensils [49]. Therefore, manufacturing industries of electrical appliances, alloys, roofing materials, etc., near the study area are the primary source of $\mathrm{Cu}$. It has been reported that the pollution of the aquatic system with $\mathrm{Cu}$ is linked with agrochemicals $[19,58]$. Cobalt (Co) concentration levels in the surface sediment varied from 2.99 to $7.92 \mathrm{mg} / \mathrm{kg}$ with an average concentration of $5.74 \mathrm{mg} / \mathrm{kg}$ (Table 6). The concentration levels of the detected cadmium $(\mathrm{Cd})$ in the samples ranged from nil (zero) to $0.06 \mathrm{mg} / \mathrm{kg}$ with a mean concentration of $0.02 \mathrm{mg} / \mathrm{kg}$ (Table 6). It was noticed that the estuarine sediments exhibited the highest concentration of $\mathrm{Zn}$, $\mathrm{Fe}, \mathrm{Mg}$, and $\mathrm{Mn}$ compared to the coastal sediments.
This may be due to the new deposition of sediments in the estuarine sediments. Average concentrations of ten trace metals were compared to the average shale value for sedimentary rock [35]. It was observed that only $\mathrm{Zn}$ contents in all sampled sites exceeded the average shale concentration for sedimentary rock. The other trace metals concentrations in all sampled sites were below the average shale values for sedimentary rock. Thus, it can be concluded that the fundamental source of trace metals at the studied sites is due to natural activities and little influence of anthropogenic activities (Table 7).

\subsection{Assessment of trace metals contamination}

The average shale concentrations for sedimentary rock were used as background concentrations for trace metals in evaluating EF [35]. $\mathrm{Zn}$ is more enriched in sampled sites CZ2 (i.e., offshore of Rambungan River opposite to small Satang Island), CZ9 (i.e., offshore of Santubong resort), and CZ10 (i.e., Santubong River estuary). The other sampled sites showed moderate enrichments of $\mathrm{Zn}$ (Table 8).

High enrichment of $\mathrm{Zn}$ was detected in a sample collected from the offshore of Batang Rambungan opposite small Satang Island i.e., CZ2(2), which could be attributed to industrial discharges and domestic sewage. The EF values for As in collected samples at sampled sites CZ1 (i.e., Rambungan River estuary), CZ2 (i.e., Batang Rambungan opposite small Satang Island), and CZ3(1) (i.e., offshore of Batang Rambungan adjacent big Satang Island) were below 1, indicating no enrichment. The EF values for As for other sampled sites were between 1 and 3, showing minor enrichments. The highest EF value for $\mathrm{Mg}$ is observed in a sample collected from Rambungan River estuary, CZ2(1), with a value of 2.49, indicating minor enrichment (Table 8). Except for CZ1(1), the other sampled sites have EF values for Mg between 1 and 3,

Table 7 Detected trace metal concentrations in surface sediments in the study sites and in some selected world rivers

\begin{tabular}{|c|c|c|c|c|c|c|c|c|c|c|c|c|}
\hline Location & Unit & $\mathrm{Zn}$ & As & $\mathrm{Fe}$ & Mg & Mn & $\mathrm{Ni}$ & $\mathrm{Cr}$ & $\mathrm{Cu}$ & Co & Cd & References \\
\hline Coastal and selected estuaries, Malaysia & $\mathrm{mg} / \mathrm{kg}$ & 133.45 & 5.13 & $16,415.17$ & 8597.46 & 142.92 & 20.18 & 37.55 & 12.01 & 5.74 & 0.02 & This study \\
\hline Langat River, Malaysia & $\mu g / g$ & - & - & $28,300.00$ & - & - & 7.84 & 21.03 & - & - & - & {$[33]$} \\
\hline River Subin, Ghana & $\mathrm{mg} / \mathrm{kg}$ & 49.70 & 4.82 & - & - & - & - & 55.80 & 6.66 & - & 1.16 & {$[59]$} \\
\hline River Ganga, India & $\mu \mathrm{g} / \mathrm{g}$ & 67.76 & - & $31,988.60$ & - & 372.04 & 26.70 & 69.94 & 29.75 & - & - & {$[51]$} \\
\hline River Tigris, Turkey & $\mathrm{mg} / \mathrm{kg}$ & 509.84 & - & - & - & - & 284.00 & 135.81 & 1257.76 & - & - & {$[60]$} \\
\hline River Jialu, China & $\mathrm{mg} / \mathrm{kg}$ & 107.58 & - & - & - & - & 42.44 & 60.80 & 39.22 & - & - & {$[61]$} \\
\hline Mangonbangon River, Philippines & $\mathrm{mg} / \mathrm{kg}$ & 213.45 & - & $22,006.14$ & - & 261.97 & 61.14 & 89.45 & 116.36 & 15.31 & - & {$[40]$} \\
\hline Shur River, Iran & Ppm & 522.00 & - & - & - & - & - & - & 9174.00 & - & - & {$[62]$} \\
\hline Korotoa River, Bangladesh & $\mathrm{mg} / \mathrm{kg}$ & - & - & - & - & - & 95.00 & 109.00 & 76.00 & - & - & {$[63]$} \\
\hline River Gomti, India & $\mathrm{mg} / \mathrm{kg}$ & 76.34 & - & - & - & - & 23.92 & 16.19 & 23.23 & - & - & [64] \\
\hline River Huaihe, China & $\mathrm{mg} / \mathrm{kg}$ & - & - & $28,300.00$ & - & - & 7.84 & 21.03 & - & - & - & [39] \\
\hline
\end{tabular}


Table 8 Enrichment of detected trace metals in surface sediments of the selected study sites

\begin{tabular}{|c|c|c|c|c|c|c|c|c|c|}
\hline Sample site code & $\mathrm{Zn}$ & As & $\mathrm{Mg}$ & $M n$ & $\mathrm{Ni}$ & $\mathrm{Cr}$ & $\mathrm{Cu}$ & Co & $\mathrm{Cd}$ \\
\hline $\mathrm{CZ1}(1)$ & 2.09 & 0.81 & 0.17 & 0.42 & 0.95 & 0.84 & 0.85 & 0.93 & 0.12 \\
\hline $\mathrm{CZ1}(2)$ & 3.51 & 0.94 & 1.58 & 0.45 & 0.55 & 1.26 & 0.79 & 0.67 & 0.11 \\
\hline$C Z 2(1)$ & 3.47 & 0.73 & 2.49 & 0.37 & 0.77 & 1.19 & 0.71 & 0.72 & 0.21 \\
\hline$C Z 2(2)$ & 5.25 & 1.94 & 1.64 & 0.39 & 1.37 & 1.73 & 1.04 & 0.73 & 0.47 \\
\hline CZ3(1) & 4.29 & 0.98 & 1.61 & 0.75 & 0.90 & 1.17 & 0.66 & 0.76 & 0.10 \\
\hline CZ3(2) & 4.29 & 1.12 & 1.61 & 0.80 & 1.05 & 1.21 & 0.65 & 0.93 & - \\
\hline CZ4(1) & 4.30 & 1.21 & 1.84 & 0.83 & 1.06 & 1.22 & 0.71 & 0.91 & 0.58 \\
\hline $\mathrm{CZ4}(2)$ & 3.87 & 1.24 & 1.52 & 0.93 & 0.83 & 1.14 & 0.68 & 0.82 & 0.17 \\
\hline CZ5 & 4.22 & 1.40 & 1.67 & 0.92 & 1.02 & 1.27 & 0.77 & 1.00 & - \\
\hline CZ6 & 4.30 & 1.27 & 1.69 & 1.11 & 1.06 & 1.27 & 0.83 & 1.02 & 0.09 \\
\hline$C Z 7(1)$ & 4.33 & 1.45 & 1.70 & 1.10 & 1.09 & 1.36 & 0.91 & 1.10 & 0.27 \\
\hline$C Z 7(2)$ & 4.20 & 1.19 & 1.55 & 1.20 & 1.04 & 1.26 & 0.86 & 1.08 & - \\
\hline CZ8 & 4.18 & 1.00 & 1.59 & 1.00 & 0.78 & 1.40 & 0.88 & 0.87 & 0.26 \\
\hline CZ9(1) & 5.15 & 1.24 & 1.93 & 0.94 & 0.80 & 1.34 & 1.05 & 1.13 & 0.42 \\
\hline CZ9(2) & 4.88 & 1.21 & 1.76 & 1.03 & 0.48 & 1.24 & 0.73 & 0.81 & - \\
\hline CZ10 & 5.01 & 1.34 & 1.86 & 0.98 & 0.52 & 1.16 & 0.74 & 0.84 & - \\
\hline Mean & 4.21 & 1.19 & 1.64 & 0.83 & 0.89 & 1.25 & 0.80 & 0.90 & 0.18 \\
\hline
\end{tabular}

Details of sample site codes are mentioned in the materials and methods section

suggesting minor enrichment. Most of the EF values for $\mathrm{Ni}$ and $\mathrm{Cr}$ in the samples were between 1 and 3 , indicating minor enrichment while, most of the estimated EFs for Co and Cd were below 1, suggesting background concentration. The high EF values obtained for some trace metals in some sampled sites may be ascribed to anthropogenic sources such as urbanization, industrial wastes deposition, etc. Trace metals bioavailability and toxicity in sediments are determined by their concentrations and chemical form $[19,65]$. Thus, trace metals in sediments with high EF values associated with labile fractions have the potential for mobility and bioavailability in aquatic environments [63].

The list of CFs of ten trace metals in surface sediments is highlighted in Table 9. The highest $\mathrm{CF}$ value for $\mathrm{Zn}$ (i.e., $C F=1.63$ ) was recorded in a sample collected from the offshore of Santubong Resort i.e., CZ9(1), suggesting moderately contamination. This may be attributed to commercial activities and vehicular effluence. Also, the CFs values obtained for $\mathrm{As}, \mathrm{Fe}, \mathrm{Mg}, \mathrm{Mn}, \mathrm{Ni}, \mathrm{Cr}, \mathrm{Cu}$, $\mathrm{Co}$, and $\mathrm{Cd}$ were below 1 , which could be ascribed to lithogenic influences. Anthropogenic activities such as residential discharges, chemical control of surrounding weeds, etc., may also play a minor role.

The Igeo values for trace metals in surface sediments from the coastal area and in four rivers estuary of Kuching Division were shown in Table 10. The Igeo values for each trace metals are as follows: -0.49 to 0.11 for $\mathrm{Zn}$, -2.74 to -1.50 for As, -2.81 to -1.94 for Fe, -1.62 to -1.22 for $\mathrm{Mg},-3.69$ to -2.71 for $\mathrm{Mn},-3.28$ to -1.91 for $\mathrm{Ni},-2.64$ to -1.49 for $\mathrm{Cr},-2.80$ to -2.18 for $\mathrm{Cu}$, -3.25 to -1.85 for $\mathrm{Cd}$, and -5.49 to -2.91 for Co. The Igeo values for $\mathrm{As}, \mathrm{Fe}, \mathrm{Mg}, \mathrm{Mn}, \mathrm{Ni}, \mathrm{Cr}, \mathrm{Cu}, \mathrm{Cd}$, and $\mathrm{Co}$ in the sediments from the study area were below class 0 , indicating unpolluted site. The high Igeo value for $\mathrm{Zn}$ was recorded in surface sediment collected from the offshore of Santubong resort i.e., CZ9(1), suggesting unpolluted to moderately polluted. The positive Igeo values for $\mathrm{Zn}$ at the sampled sites from CZ4(2) to CZ10 may be attributed to sewages discharges and/or effluents.

The PLI values for trace metals of the studied site were summarised in Table 10. The PLI values varied from 0.22 to 0.52 and with a mean value of 0.31 . This indicates that there has been no occurrence of contamination in the studied site. High PLI value was found in sediment from the offshore of Telaga Air opposite to small Satang Island. In contrast, low PLI value was observed in sediment from the Rambungan River estuary and the offshore of Batang Rambungan opposite small Satang Island. Based on the PLI values, no significant disturbances of the aquatic environment due to heavy metals pollution were observed.

\subsection{Ecotoxicological risk assessment}

To determine the risks associated with trace metals toxicity on organisms living at or near the bottom of the aquatic bodies (i.e., bodies of water forming a physiological feature for example a river, sea, etc.,); trace metals concentrations were compared with consensus-based 
Table 9 Contamination levels of detected trace metals in surface sediments of the selected study sites

\begin{tabular}{|c|c|c|c|c|c|c|c|c|c|c|}
\hline Sample site code & $\mathrm{Zn}$ & As & $\mathrm{Fe}$ & $\mathrm{Mg}$ & $\mathrm{Mn}$ & $\mathrm{Ni}$ & $\mathrm{Cr}$ & $\mathrm{Cu}$ & Co & $\mathrm{Cd}$ \\
\hline CZ1(1) & 0.60 & 0.23 & 0.29 & 0.48 & 0.12 & 0.27 & 0.24 & 0.25 & 0.27 & 0.03 \\
\hline $\mathrm{CZ1}(2)$ & 1.07 & 0.29 & 0.30 & 0.48 & 0.14 & 0.17 & 0.38 & 0.24 & 0.21 & 0.03 \\
\hline CZ2(1) & 1.10 & 0.23 & 0.32 & 0.53 & 0.12 & 0.24 & 0.38 & 0.22 & 0.23 & 0.07 \\
\hline CZ2(2) & 1.13 & 0.42 & 0.22 & 0.54 & 0.12 & 0.29 & 0.37 & 0.22 & 0.25 & 0.10 \\
\hline CZ3(1) & 1.41 & 0.32 & 0.33 & 0.54 & 0.13 & 0.30 & 0.39 & 0.22 & 0.31 & 0.03 \\
\hline CZ3(2) & 1.44 & 0.38 & 0.34 & 0.54 & 0.14 & 0.35 & 0.41 & 0.22 & 0.32 & - \\
\hline$C Z 4(1)$ & 1.47 & 0.42 & 0.35 & 0.64 & 0.17 & 0.37 & 0.42 & 0.24 & 0.32 & 0.07 \\
\hline $\mathrm{CZ4}(2)$ & 1.52 & 0.48 & 0.39 & 0.60 & 0.18 & 0.32 & 0.45 & 0.27 & 0.37 & 0.07 \\
\hline CZ5 & 1.55 & 0.51 & 0.37 & 0.61 & 0.18 & 0.38 & 0.47 & 0.28 & 0.37 & - \\
\hline CZ6 & 1.56 & 0.46 & 0.36 & 0.61 & 0.22 & 0.38 & 0.46 & 0.30 & 0.40 & 0.03 \\
\hline$C Z 7(1)$ & 1.58 & 0.53 & 0.37 & 0.62 & 0.22 & 0.38 & 0.50 & 0.33 & 0.42 & 0.10 \\
\hline$C Z 7(2)$ & 1.62 & 0.46 & 0.37 & 0.60 & 0.23 & 0.40 & 0.47 & 0.33 & 0.33 & - \\
\hline CZ8(1) & 1.59 & 0.37 & 0.38 & 0.61 & 0.19 & 0.30 & 0.53 & 0.33 & 0.36 & 0.10 \\
\hline CZ9(1) & 1.63 & 0.39 & 0.32 & 0.61 & 0.18 & 0.25 & 0.43 & 0.33 & 0.26 & 0.13 \\
\hline CZ9(2) & 1.58 & 0.39 & 0.33 & 0.57 & 0.19 & 0.16 & 0.40 & 0.24 & 0.26 & - \\
\hline CZ10 & 1.61 & 0.43 & 0.32 & 0.60 & 0.19 & 0.17 & 0.37 & 0.24 & 0.26 & - \\
\hline Mean & 1.40 & 0.33 & 0.34 & 0.57 & 0.17 & 0.30 & 0.42 & 0.27 & 0.31 & 0.05 \\
\hline
\end{tabular}

Details of sample site codes are mentioned in the materials and methods section

Table 10 Geo-accumulation indices (lgeo) and pollution load indices (PLI) values of detected trace metals in surface sediments of the selected study sites

\begin{tabular}{|c|c|c|c|c|c|c|c|c|c|c|c|}
\hline Sample site code & $\mathrm{Zn}$ & As & $\mathrm{Fe}$ & $\mathrm{Mg}$ & $\mathrm{Mn}$ & $\mathrm{Ni}$ & $\mathrm{Cr}$ & $\mathrm{Cu}$ & Co & $\mathrm{Cd}$ & PLI \\
\hline$C Z 1(1)$ & -1.32 & -2.69 & -2.38 & -1.62 & -3.64 & -2.45 & -2.64 & -2.62 & -2.49 & -5.49 & 0.22 \\
\hline $\mathrm{CZ1}(2)$ & -0.49 & -2.38 & -2.30 & -1.58 & -3.46 & -3.17 & -1.97 & -2.64 & -2.84 & -5.49 & 0.24 \\
\hline$C Z 2(1)$ & -0.45 & -2.74 & -2.25 & -1.49 & -3.68 & -2.64 & -2.00 & -2.74 & -2.72 & -4.49 & 0.22 \\
\hline CZ2(2) & -0.41 & -1.85 & -2.81 & -1.47 & -3.69 & -2.35 & -2.01 & -2.76 & -3.25 & -3.91 & 0.29 \\
\hline CZ3(1) & -0.09 & -2.22 & -2.19 & -1.46 & -3.56 & -2.35 & -1.96 & -2.80 & -2.59 & -5.91 & 0.28 \\
\hline CZ3(2) & -0.06 & -2.00 & -2.16 & -1.45 & -3.44 & -2.09 & -1.88 & -2.77 & -2.27 & - & 0.34 \\
\hline $\mathrm{CZ4}(1)$ & -0.01 & -1.84 & -2.12 & -1.22 & -3.17 & -2.03 & -1.82 & -2.62 & -2.25 & -2.91 & 0.34 \\
\hline$C Z 4(2)$ & 0.02 & -1.63 & -1.94 & -1.32 & -3.10 & -2.21 & -1.75 & -2.48 & -2.23 & -4.49 & 0.35 \\
\hline CZ5 & 0.05 & -1.55 & -2.03 & -1.28 & -3.06 & -2.00 & -1.69 & -2.40 & -2.02 & - & 0.52 \\
\hline CZ6 & 0.06 & -1.70 & -2.05 & -1.28 & -2.80 & -1.97 & -1.71 & -2.31 & -1.91 & -5.49 & 0.34 \\
\hline$C Z 7(1)$ & 0.08 & -1.50 & -2.04 & -1.26 & -2.79 & -1.92 & -1.60 & -2.18 & -1.85 & -3.91 & 0.40 \\
\hline$C Z 7(2)$ & 0.11 & -1.71 & -1.96 & -1.31 & -2.71 & -1.91 & -1.63 & -2.18 & -1.85 & - & 0.49 \\
\hline CZ8 & 0.08 & -2.01 & -1.98 & -1.29 & -2.96 & -2.33 & -1.49 & -2.19 & -2.18 & -3.91 & 0.37 \\
\hline CZ9(1) & 0.12 & -1.93 & -2.45 & -1.28 & -3.04 & -2.56 & -1.82 & -2.18 & -2.06 & -3.49 & 0.35 \\
\hline CZ9(2) & 0.08 & -1.93 & -2.21 & -1.38 & -3.01 & -3.28 & -1.90 & -2.65 & -2.45 & - & 0.3 \\
\hline CZ10 & 0.11 & -1.80 & -2.22 & -1.31 & -3.69 & -3.16 & -1.79 & -2.64 & -2.47 & - & 0.3 \\
\hline Mean & -0.11 & -1.97 & -1.62 & -1.38 & -3.24 & -2.40 & -1.85 & -2.07 & -2.34 & -3.09 & 0.31 \\
\hline
\end{tabular}

Details of sample site codes are mentioned in the materials and methods section

threshold effect concentration (TEC), probable effect concentration (PEC), and the midway concentration between TEC and PEC (i.e., MEC) values fetched from the sediments quality guidelines developed by ANZECC/ ARMCANZ, 2000 [38]. The TEC, MEC, and PEC data of eight out of the ten detected trace metals in the samples were available in the sediments quality guidelines developed by ANZECC/ARMCANZ, 2000. Thus, risks associated with 8 trace metals toxicity on bottom-dwelling organisms in the study area were appraised. The comparisons of consensus-based sediment-quality guidelines (SQGs) with detected trace metals levels in the surface 
sediments of the selected study sites were presented in Table 11. Twenty-five percent of the samples contained $\mathrm{Zn}$ concentrations less than the TEC value for $\mathrm{Zn}$, while $62.50 \%$ of the sampled sites contained Ni concentrations lower than the TEC value for Ni (Table 11). In addition, $81.25 \%$ of the samples had $\mathrm{Cr}$ concentrations below the TEC value for Cr. All the sampled sites contained As, Fe, $\mathrm{Mn}, \mathrm{Cu}$, and $\mathrm{Cd}$ concentrations below TEC values for As, $\mathrm{Fe}, \mathrm{Mn}, \mathrm{Cu}$, and $\mathrm{Cd}$, respectively. None of the samples contained trace metals exceeding the PEC values. Trace metals concentrations in surface sediments below TEC values were unlikely to negatively impact bottom-dwelling organisms [60]. Seventy-five percent of the sampled sites contained $\mathrm{Zn}$ concentrations exceeding TEC but equal or less than MEC, whereas $37.50 \%$ of the samples had Ni concentrations surpassing TEC but equal or less than MEC. Furthermore, $18.75 \%$ of the sampled sites contained $\mathrm{Cr}$ concentrations above TEC but equal or less than MEC.

The monomial potential ecological risks (Ei) for each trace metal and possible environmental risk index (RI) in all collected samples from the coastal and in four rivers estuary were detailed in Table 12. The RI index was computed based on the eight heavy metals (i.e., $\mathrm{Zn}$, As, $\mathrm{Ni}, \mathrm{Cr}, \mathrm{Cu}, \mathrm{Co}$, and $\mathrm{Cd}$ ). The mean potential ecological risk for studied tace metals follow the order of $\mathrm{Mn}{ }^{<} \mathrm{Cr}$ ${ }^{<} \mathrm{Ni}^{<} \mathrm{Cu}<\mathrm{Zn}^{<} \mathrm{Cd}^{<} \mathrm{Co}^{<}$As. Among the analysed trace metals; $\mathrm{Mn}, \mathrm{Cr}$, and $\mathrm{Ni}$ had relatively lower RI values due

Table 11 Comparisons of consensus-based sediment-quality guidelines (SQGs) with detected trace metals levels in the surface sediments of the selected study sites

\begin{tabular}{|c|c|c|c|c|c|c|c|c|}
\hline & $\mathrm{Zn}$ & As & $\mathrm{Fe}$ & $M n$ & $\mathrm{Ni}$ & $\mathrm{Cr}$ & $\mathrm{Cu}$ & $C d$ \\
\hline \multicolumn{9}{|l|}{ SQGS } \\
\hline TEC & 120 & 9.8 & 20,000 & 460 & 23 & 43 & 32 & 0.99 \\
\hline MEC & 290 & 21.4 & 30,000 & 780 & 36 & 76.5 & 91 & 3.00 \\
\hline PEC & 460 & 33 & 40,000 & 1100 & 49 & 110 & 150 & 5.00 \\
\hline$\%$ sample sites of detected trace metal less than TEC & 25.00 & 100.00 & 100.00 & 100.00 & 62.50 & 81.25 & 100.00 & 100.00 \\
\hline $\begin{array}{l}\% \text { sample sites of detected trace metal greater than TEC but } \\
\text { equal or less than MEC }\end{array}$ & 75.00 & 0 & 0 & 0 & 37.50 & 18.75 & 0 & 0 \\
\hline \% sample sites of detected trace metal greater than PEC & 0 & 0 & 0 & 0 & 0 & 0 & 0 & 0 \\
\hline
\end{tabular}

Details of detected trace metals value in each sample site are mentioned in Table 6 in the results section

Table 12 The potential ecological risk index values (RI) of detected trace elements in surface sediments of the selected study sites

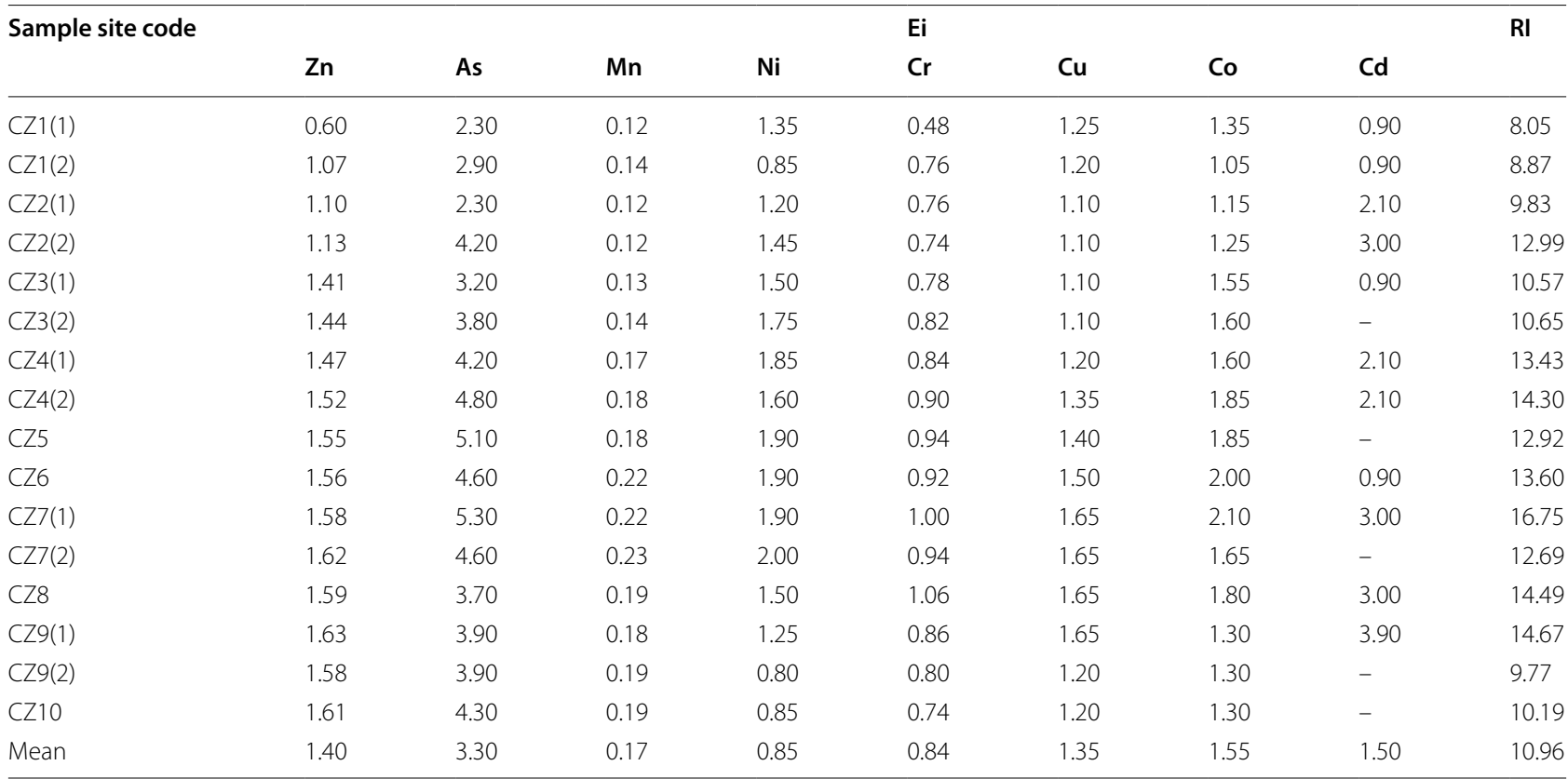

Details of sample site codes are mentioned in the materials and methods section 
to their low toxicity response factors. Furthermore, RI results in the surface sediment varied from 8.05 (CZ1) to 16.75 (CZ7). The obtained RI values for all sampled sites were lower than 150, indicating that the sediments in the studied site posed a minimum risk. The most significant Ei values were recorded for As, because, based on Hakanson's approach, the toxic response of this metal is the highest. Although, it does not show a high ecological risk in the coastal and in four rivers estuary sediment, owing to the fact that the quantified As values are positioned below the acceptable limit. The other metals that made an important contribution to the final result of the $\mathrm{RI}$ index include $\mathrm{Cu}, \mathrm{Ni}$ and $\mathrm{Co}$.

\subsection{Trace metal pollution source}

Evaluating the sources of trace metals can help comprehend their distribution. Thus, Pearson's correlation analysis and principal component analysis (PCA) were employed to analyze the relationship and source of the trace metals [66, 67].

The correlation coefficient matrix recording the Pearson's product-moment coefficients were shown in Table 13. Positive correlations were recorded between ( $\mathrm{Zn}$ and $\mathrm{As}),(\mathrm{Zn}$ and $\mathrm{Fe}$ ), ( $\mathrm{Zn}$ and $\mathrm{Mg}$ ), ( $\mathrm{Zn}$ and $\mathrm{Mn}$ ), ( $\mathrm{Zn}$ and $\mathrm{Cr}$ ), (As and $\mathrm{Mg}$ ), (As and $\mathrm{Cr}$ ), (As and $\mathrm{Co}$ ), (Fe and $\mathrm{Mg}$ ), (Fe and $\mathrm{Mn}$ ), (Fe and $\mathrm{Cr}$ ), (Fe and $\mathrm{Co}$ ), (Mg and $\mathrm{Mn}$ ), ( $\mathrm{Mg}$ and $\mathrm{Cr}$ ), (Mg and $\mathrm{Co}),(\mathrm{Mn}$ and $\mathrm{Cr}$ ), ( $\mathrm{Mn}$ and $\mathrm{Cu}$ ), (Mn and $\mathrm{Co}),(\mathrm{Ni}$ and $\mathrm{Co}),(\mathrm{Cr}$ and $\mathrm{Cu}),(\mathrm{Cr}$ and $\mathrm{Co})$, and $(\mathrm{Cu}$ and $\mathrm{Co})$ at 0.01 significant level. Positive correlations were also noticed between $(\mathrm{Zn}$ and $\mathrm{Cu}),(\mathrm{Zn}$ and $\mathrm{Co})$, (As and $\mathrm{Ni}),(\mathrm{As}$ and $\mathrm{Cu}),(\mathrm{Fe}$ and $\mathrm{Cu}),(\mathrm{Mg}$ and $\mathrm{Cu}),(\mathrm{Mg}$ and $\mathrm{Cd}),(\mathrm{Mn}$ and $\mathrm{Cu})$, and $(\mathrm{Mn}$ and $\mathrm{Cd})$ at 0.05 significant level. The high positive interrelationships between studied trace metals are indication of a common source.
In this current study, PCA was conducted based on the evaluated concentrations of trace metals with varimax rotation. The Kaiser-Meyer-Olkin (KMO) test gives 0.49 , and the Barlett test gives $99.82(d f=45)$, showing strong interrelationships among variables and substantiating that PCA can be used to reduce the dimensionality of variables. Based on PCA results (Fig. 2 and Additional file 1: Table S1), PCA1 accounts for $67.33 \%$ of the variation, and its representative congeners include $\mathrm{Mn}, \mathrm{Mg}, \mathrm{Zn}, \mathrm{Co}, \mathrm{Cr}, \mathrm{As}, \mathrm{Cu}, \mathrm{Fe}$, and $\mathrm{Ni}$, suggesting a common source that is probably exogenous discharge $[68,69]$. PCA2 accounts for $11.80 \%$ of the variation, and its representative congeners are $\mathrm{Cd}$ and $\mathrm{Mg}$, implying a similar source that may be attributed to industrial and domestic discharge. The weak correlation between $\mathrm{Cd}$ and other trace metals is an indication of different external sources.

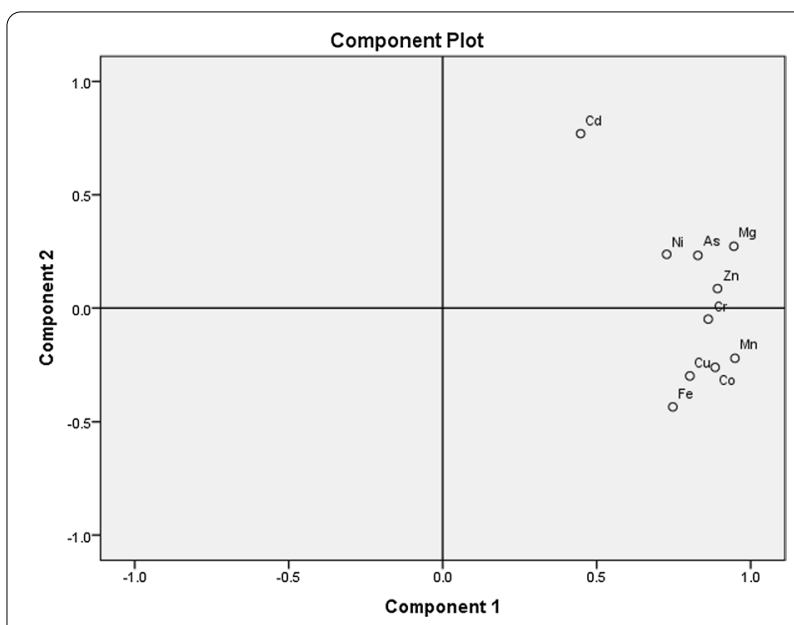

Fig. 2 Principal component profile of the ten trace metals collected from the sediments of the selected sampling sites

Table 13 Correlation coefficients between different detected trace metals in surface sediments of the selected study sites

\begin{tabular}{|c|c|c|c|c|c|c|c|c|c|c|}
\hline & $Z n$ & As & $\mathrm{Fe}$ & $\mathrm{Mg}$ & $M n$ & $\mathrm{Ni}$ & $\mathrm{Cr}$ & $\mathrm{Cu}$ & Co & $\mathrm{Cd}$ \\
\hline $\mathrm{Zn}$ & 1 & & & & & & & & & \\
\hline As & $0.747^{* *}$ & 1 & & & & & & & & \\
\hline $\mathrm{Fe}$ & $0.630^{* *}$ & 0.48 & 1 & & & & & & & \\
\hline $\mathrm{Mg}$ & $0.849^{* *}$ & $0.801^{* *}$ & $0.625^{* *}$ & 1 & & & & & & \\
\hline $\mathrm{Mn}$ & $0.768^{* *}$ & $0.741^{* *}$ & $0.715^{* *}$ & $0.790^{* *}$ & 1 & & & & & \\
\hline $\mathrm{Ni}$ & 0.268 & $0.543^{*}$ & 0.477 & 0.4790 & 0.375 & 1 & & & & \\
\hline $\mathrm{Cr}$ & $0.807^{* *}$ & $0.686^{* *}$ & $0.711^{* *}$ & $0.739^{* *}$ & $0.740^{* *}$ & 0.496 & 1 & & & \\
\hline $\mathrm{Cu}$ & $0.499 *$ & $0.511^{*}$ & $0.581^{*}$ & $0.612^{*}$ & $0.799^{*}$ & 0.452 & $0.707^{* *}$ & 1 & & \\
\hline Co & $0.619^{*}$ & $0.630^{* *}$ & $0.808^{* *}$ & $0.726^{* *}$ & $0.832^{* *}$ & $0.667^{* *}$ & $0.667^{* *}$ & $0.812^{* *}$ & 1 & \\
\hline $\mathrm{Cd}$ & 0.435 & 0.377 & 0.065 & $0.649^{*}$ & 0.252 & 0.331 & 0.342 & 0.241 & 0.267 & 1 \\
\hline
\end{tabular}

**Correlation is significant at the 0.01 level (2-tailed)

${ }^{*}$ Correlation is significant at the 0.05 level (2-tailed)

Computed values were for all the selected study sites 


\section{Discussion}

The coastal and four rivers estuary (i.e., Santubong, Salak, Sibu, and Rambungan) is a vital agricultural and transportation water resources for the Kuching Division of Sarawak. Therefore, it is necessary to evaluate the pollution status, ecotoxicological risks, and likely sources of trace metals in the surface sediments of the coastal and four selected rivers estuary. In aquatic ecosystems, sediment is both a source and a sink of trace metals. Thus, this study investigated ten trace metals in surface sediments from the coastal and four rivers estuary.

In sediment samples, all ten trace metals were detected, and their average concentration followed the order of $\mathrm{Cd}$ < $\mathrm{As}$ < $\mathrm{Co}{ }^{<} \mathrm{Cu}^{<} \mathrm{Ni}^{<} \mathrm{Cr}^{<} \mathrm{Zn}{ }^{<} \mathrm{Mn}^{<} \mathrm{Mg}$ < $\mathrm{Fe}$. The assessment showed moderate $\mathrm{As}, \mathrm{Mg}, \mathrm{Cr}$, and Ni pollution. The average concentrations of trace metals in surface sediment were compared with other studies of trace metals in rivers in the world (Table 7). The $\mathrm{Zn}$ concentrations detected in all sampled sites were lower than $\mathrm{Zn}$ content in Tigris River sediment, Mangobangon River sediment [40], and shur River sediment [62]. Furthermore, the average concentrations of $\mathrm{Cu}$ in the studied area were below $\mathrm{Cu}$ contents reported values from surface sediments from Tigris River [60], Mangonbangon River sediment [40], Jialu River sediment [61], Krotoa River sediment [63], and Gomti River sediment [64] (Table 7). The mean concentrations of $\mathrm{Ni}$ in all sediment samples were lower than values reported in surface sediments from Tigris River [60], Jialu River [61], Mangonbangon River [40], Korotoa River [63], and Gomti River [64]. The average concentration of $\mathrm{Cr}$ in this current study was below the detected level of $\mathrm{Cr}$ in surface sediment's from the Subin River [59], Tigris River [60], Mangonbangon River [40], and Korotoa River [63]. The Mn in the sediments of Mangonbangon River [40] exceeded the values of Mn concentration in this study. Furthermore, the detected level of $\mathrm{Cd}$ was higher than $\mathrm{Cd}$ levels detected in surface sediments from the Subin River [59]. In contrast, the average concentrations of detected Fe in this study were below the concentrations of detected Fe in surface sediments from Mangonbangon River [40] and Huaihe River [39].

Although the single factor pollution indices (i.e., EF, CF, and Igeo) method has been widely used, it is functional to a single pollutant. Thus, it does not consider a mixture of trace metals primarily available in the pollution conditions. However, it has helped to ascertain how much the available metal in sampled sites has elevated relative to average natural abundance due to human activity [7]. Nevertheless, an integrated pollution index (i.e., PLI) was employed to help considering the mixture of trace metals present in the contamination conditions. Based on EF results, the trend of trace metal enrichments in all sampled sites followed the order: $\mathrm{Cd}^{<} \mathrm{Cu}^{<} \mathrm{Mn}{ }^{<} \mathrm{Ni}<\mathrm{Co}$ ${ }^{<} \mathrm{As}^{<} \mathrm{Mg}{ }^{<} \mathrm{Cr}{ }^{<} \mathrm{Zn}$ (Table 8). Generally, the evaluation showed minor enrichments of almost all the trace metals in all sampled sites. The enrichments of trace metals may be attributed to both natural processes and anthropogenic sources, including industrial wastes deposition, sewage discharges, and urbanization. The trend of obtained CFs values for trace metals in all samples followed the order: $\mathrm{Cd}^{<} \mathrm{Mn}^{<} \mathrm{Cu}^{<} \mathrm{Ni}^{<} \mathrm{Co}^{<} \mathrm{As}^{<} \mathrm{Fe}^{<} \mathrm{Cr}^{<} \mathrm{Mg}^{<} \mathrm{Zn}$. Almost all the trace metals CF values were below 1 in all sampled sites, suggesting minimum contamination conditions except for $\mathrm{Zn}$, which showed moderate contamination in some sample sites (Table 10). All the trace metals except $\mathrm{Zn}$ have Igeo values lower than 0 , indicating background concentration. Generally, the Igeo values obtained for $\mathrm{Zn}$ indicate a minor role played by anthropogenic activities. From the PLI results; there is no significant disturbance of the aquatic environment due to trace metals pollution. The PLI values can be used as baseline contamination levels in the future for pollution monitoring in a selected site.

The ecological risk index has been demonstrated as a highly productive tool to evaluate the total pollution of sediments of an aquatic ecosystem [54]. Protano et al. narrated that the inadequacy of updated reference metal values for a specified ecological site or geographical zone can lead to underestimating or overestimating the actual pollution load in sediments and the environmental risk index [70]. Decena et al. reported that to get an accurate estimation of the ecological risk of metals, regular updates of reference concentrations after a certain period are required, especially in geological zones with sensitive ecological environments [40]. Average concentrations of trace metals were compared with sediment-quality guidelines (SQGs). It was observed that almost all the trace metals in all sampled sites were below TEC values for respective trace metals except $\mathrm{Zn}, \mathrm{Ni}$, and $\mathrm{Cr}$, in which their concentrations exceeded TEC values for $Z n$ i.e., from sampled site CZ3(1) to CZ10; Ni i.e., from sampled site CZ3(2) to CZ7(2); and Cr i.e., from sampled site CZ7(1) to CZ8. It can be deduced that trace metals concentrations in sampled sites above TEC but equal or less than MEC may probably affect bottom-dwelling organisms. According to the IR results, a low potential ecological risk from all the trace metals in all sampled sites was noticed.

Since the studied trace metals in sediments have a moderate adverse health impact on the biome, it is necessary to assess and control the pollution source. Trace elements in sediments often show complex interrelationships. Many factors influence their relative abundance, for instance, parent materials and rocks, anthropogenic activities, and soil formation processes [42, 71]. Pearson's correlation analysis was used to assess the relationship between the trace metals. Principal component analysis (PCA) 
was performed to evaluate the most common pollution sources. Correlation analysis and PCA results showed strong positive interrelationships between trace metals, suggesting a common source or similar geochemical characteristics except for $\mathrm{Cd}$, which showed a weak correlation with other trace metals except for Mg (Fig. 2 and Additional file 1: Table S1). The inverse relationships between $\mathrm{Cd}$ and other trace metals are indication of different external sources.

Despite a low level of absolute content, the As, Cd, and $\mathrm{Ni}$ in sediment already render a moderate monomial ecological risk and therefore calls urgent attention. The primary source of trace metals in sediment is natural processes and sediment properties. Anthropogenic activities may also influence trace metals distribution of the studied area.

\section{Conclusions}

The concentrations of ten trace metals in surface sediments collected from the coastal and in four rivers estuary in Sarawak, Malaysia, were examined. All ten trace metals were detected at all sampled sites, with a concentration lower than the average shale value for sedimentary rock except Zn. Pollution appeared more severe in the coastal of the studied area, probably due to point source contamination nearby. Among the trace metals of interest, $\mathrm{Zn}, \mathrm{Ni}$, and $\mathrm{Cr}$ concentrations surpassed the TEC values and should be carefully monitored and remediated because they may cause unfavorable impacts on bottom-dwelling organisms. Potential ecotoxicological risk analysis of trace metals concentrations in surface sediments indicated that most sampling sites posed a minor or moderate ecological risk. Correlation analysis and principal component analysis revealed that nine trace metals $(\mathrm{Zn}, \mathrm{As}, \mathrm{Fe}, \mathrm{Mg}, \mathrm{Ni}, \mathrm{Cr}, \mathrm{Cu}$, and $\mathrm{Co}$ ) were derived from common sources. The results will guide controlling trace metal contamination and protecting agricultural and transportation water sources in the coastal and the four rivers estuary in the Kuching Division of Sarawak.

\footnotetext{
Abbreviations

EF: Enrichment factor; CF: Contamination factor; Igeo: Geo-accumulation index; PLI: Pollution load index; SQGs: Sediment quality guidelines; TEC: Threshold effect concentration; PEC: Probable effect concentration; RI: Risk index; PCA: Principal component analysis; ICP-OES: Inductively coupled plasma- optical emission spectroscopy.
}

\section{Supplementary Information}

The online version contains supplementary material available at https://doi. org/10.1186/s43088-022-00199-y.

Additional file 1. Total variance explained and component matrices for trace metals in the surface sediments of the coastal and in four rivers estuary of Sarawak.
Acknowledgements

The authors acknowledge the contribution of colleagues from the Analytical Chemistry Laboratory, Faculty of Resource Science and Technology (FRST),

Universiti Malaysia Sarawak.

\section{Authors' contributions}

EAA, ZA, and RW conceived of the study and carried out the design of the experiment. EAA carried out the sample preparation and analysis, EAA, ZA, and JRF assessed the data, and EAA, ZA, and RW helped to draft and edited the manuscript. All authors read and approved the final manuscript.

\section{Funding}

The consumables and field trip cost of the entire research were financially supported by Universiti Malaysia Sarawak, Postgraduate Research Grant, with Grant Code: F07/PGRG/1896/2019.

\section{Availability of data and materials}

All data generated or analyzed during this study are included in this paper.

\section{Declarations}

Ethical approval and consent to participate

Not applicable.

\section{Consent for publication}

Not applicable.

\section{Competing interests}

The authors declare that they have no competing interests.

\section{Author details}

${ }^{1}$ Department of Chemistry, Faculty of Resource Science and Technology, Universiti Malaysia Sarawak, 94300 Kota Samarahan, Sarawak, Malaysia. ${ }^{2}$ Department of Nuclear Science and Applications, Graduate School of Nuclear and Allied Sciences, University of Ghana, AE1, Kwabenya-Accra, Ghana.

Received: 9 November 2020 Accepted: 17 January 2022

Published online: 29 January 2022

\section{References}

1. Zhang C, Yu Z-G, Zeng G-M, Jiang M, Yang Z-Z, Cui F, Zhu M-Y, Shen L-Q, Hu L (2014) Effects of sediment geochemical properties on heavy metal bioavailability. Environ Int 73:270-281

2. Bryan GW, Langston WJ (1992) Bioavailability, accumulation and effects of heavy metals in sediments with special reference to United Kingdom estuaries: a review. Environ Pollut 76:89-131

3. Redwan M, Elhaddad E (2017) Heavy metals seasonal variability and distribution in Lake Qaroun sediments, El-Fayoum. Egypt J Afr Earth Sci 134:48-55

4. Nguyen CC, Hugie CN, Kile ML, Navab-Daneshmand T (2019) Association between heavy metals and antibiotic-resistant human pathogens in environmental reservoirs: a review. Front Environ Sci Eng 13:46

5. Li Z, Liu J, Chen H, Li Q, Yu C, Huang X, Guo H (2019) Water environment in the Tibetan Plateau: heavy metal distribution analysis of surface sediments in the Yarlung Tsangpo River Basin. Environ Geochem Health 17:1-9

6. Asare EA, Assim ZB, Wahi RB, Droepenu EK, Durumin Inya NM (2019) Geochemistry examination of surface sediments from Sadong River, Sarawak, Malaysia: validation of ICP-OES assessment of selected heavy metals. Eurasian J Anal Chem 14(3): emEJAC-00337.

7. Asare EA, Assim ZB, Wahi RB, Bakeh T, Dapaah SS (2021) Trend analysis of anthropogenic activities affecting trace metals deposition in core sediments from the coastal and four rivers estuary of Sarawak, Malaysia. Environ Sci Pollut Res. https://doi.org/10.1007/s11356-021-17008-1

8. Asare EA, Assim ZB, Wahi R (2021) Validation of an analytical technique, distribution, and risk assessment of aliphatic and polycyclic aromatic hydrocarbons in surface sediments of the coastal and selected estuaries of Sarawak. Arab J Geosci 14:1943 
9. Jia L, Liu H, Kong Q, Li M, Wu S, Wu H (2019) Interactions of high-rate nitrate reduction and heavy metal mitigation in iron-carbon-based constructed wetlands for purifying contaminated groundwater. Water Res 169:115285

10. Chen R, Chen H, Song L, Yao Z, Meng F, Teng Y (2019) Characterization and source apportionment of heavy metals in the sediments of Lake Tai (China) and its surrounding soils. Sci Total Environ 694:133819

11. Pejman A, Bidhendi GN, Ardestani M, Saeedi M, Baghvand A (2015) A new index for assessing heavy metals contamination in sediments: a case study. Ecol Ind 58:365-373

12. Huang Z, Zhao W, Xu T, Zheng B, Yin D (2019) Occurrence and distribution of antibiotic resistance genes in the water and sediments of Qingcaosha Reservoir, Shanghai, China. Environ Sci Eur 31:1-9

13. Asare EA (2021) Impact of the illegal gold mining activities on Pra River of Ghana on the distribution of potentially toxic metals and naturally occurring radioactive elements in agricultural land soils. Chem Afr. https://doi. org/10.1007/s42250-021-00285-1

14. Shyleshchandran MN, Mohan M, Ramasamy EV (2018) Risk assessment of heavy metals in Vembanad Lake sediments (south-west coast of India), based on acid-volatile sulfide (AVS)-simultaneously extracted metal (SEM) approach. Environ Sci Pollut Res 25:7333-7345

15. Asare EA, Wahi R, Gyampoh AO, Omorinoye AO (2021) Determination of rare earth elements and its distribution pattern from the core sediments by $k_{0}$-intrumental neutron activation analysis. Indian J Environ Prot 41(7):736-744

16. Kouidri M, Youcef ND, Benabdellah I, Ghoubali R, Bernoussi A, Lagha A (2016) Enrichment and geoaccumulation of heavy metals and risk assessment of sediments from coast of Ain Temouchent (Algeria). Arab J Geosci 9:354

17. Asare EA, Assim ZB, Wahi RB, Droepenu EK, Wilson F (2019) Validation of the atomic absorption spectroscopy (AAS) for heavy metal analysis and geochemical exploration of sediment samples from the Sebangan River. Adv Anal Chem 9(2):23-33

18. Omorinoye AO, Assim ZB, Jusoh IB, Durumin lya NI, Asare EA (2019) Vertical profile of heavy metal contamination in sediments from Sadong River Sarawak, Malaysia. Indian J Environ Prot 39(11):971-978

19. Yang Y, Chen F, Zhang L, Liu J, Wu S, Kang M (2012) Comprehensive assessment of heavy metal contamination in the sediment of the Pearl River Estuary and adjacent shelf. Mar Pollut Bull 64:1947

20. Yi Y, Yang Z, Zhang S (2011) Ecological risk assessment of heavy metals in sediment and human health risk assessment of heavy metals in fishes in the middle and lower reaches of the Yangtze River basin. Environ Pollut 159:2575-2585

21. Porstner U (1989) Lecture notes in earth sciences (Contaminated Sediments). Springer, Berlin, pp 107-109

22. Wu B (2014) Potential ecological risk of heavy metals and metalloid in the sediments of Wuyuer River basin, Heilongjiang province, China. Ecotoxicology 23:589-600

23. Hilton J, Davison W, Ochsenbein U (1985) A mathematical model for the analysis of sediment coke data. Chem Geol 48:281-291

24. Liu Y, Guo HC, Yu YJ, Huang K, Wang Z (2007) Sediment chemistry and the variation of three altiplano lakes to recent anthropogenic impacts in southwestern China. Water SA 33(2):305-310

25. Pekey H, Karakas D, Ayberk S, Tolun L, Bakoglu M (2004) Ecological risk assessment using trace elements from surface sediments of Izmit Bay (Northeastern Marmara Sea) Turkey. Mar Pollut Bull 48(946):953

26. Gao S (2019) Geomorphology and Sedimentology of Tidal Flats. GME Perillo, E Wolanski, DR Cahoon, CS, Coastal Wetlands (2nd ed), Elsevier, Pages $259-381$

27. United State Environmental Protection Agency, USEPA (2009) Risk-based Concentration Table. Philadelphia PA: United States Environmental Protection Agency, Washington, DC

28. Hossner LR (1996) Dissolution for total elemental analysis. In: Sparks, Bigham JM (eds) Methods of soil analysis: part 3 chemical methods. SSSA and ASA, Madison, WI, pp 49-64

29. Sahnquillo A, Rigo IA, Rauret G (2003) Overview of the use of leaching/ extraction tests for risk assessment of trace metals in contaminated soils and sediments. Trends Anal Chem 22(3):152-159

30. Gao H (2001) Pollution chemistry and ecology toxicity of multisand river. Zhenzhou, Yellow River. Hydraulic Publication, pp 95-96 (in Chinese).
31. Maria AT, Margarida MC, Maria LS (2003) Quality assurance program for the chemical characterization of soils. Accredit Qual Assur 8(7-8):323-333

32. Muller G (1979) Schwermetalle in den sediments des Rheins-Veranderungen Seitte. Umschan 78:778-783

33. Kadhum SA, Ishak MY, Zulkifli SZ, Hashim RB (2015) Evaluation of the status and distributions of heavy metal pollution in surface sediments of the Langat River Basin in Selangor Malaysia. Mar Pollut Bull 101(1):391-396

34. Hakanson $L$ (1980) An ecological risk index for aquatic pollution control of sediment ecological approach. Water Res 14(8):975-1001

35. Turekian KK, Wedepohl KH (1961) Distribution of the elements in some major units of the earth's crust. Geo Soc Am Bull 72(2):175-192

36. Saleem M, Aftab J, Hasaney SI, Kahkishan S, Haider SW, Muzzaffar M (2016) Toxicity level, Ecological risk assessment of Heavy metals and distribution in the surface sediment of Hub River, Hub River estuary and Gadani coast, Baluchistan, Pakistan. Int Netw Nat Sci 8(5):219-232

37. Tomlinson DC, Wilson DJ, Harris CR, Jeffrey DW (1980) Problem in assessment of heavy metals in estuaries and the formation of pollution index. Helgol Wiss Meeresunlter 33:566-575

38. ANZECC, and ARMCANZ (2000) Australian and New Zealand Guidelines for Fresh and Marine Water Quality

39. Wang J, Liu G, Lu L, Liu H (2016) Metal distribution and bioavailability in surface sediments from the Huaihe River, Anhui, China. Environ Monit Assess 188(1):3

40. Decena SCP, Arguelles MS, Robel LL (2018) Assessing heavy metal contamination in surface sediments in an urban river in the Philippines. Pol J Environ Stud 27(5):1983-1995

41. Florida Department of Environmental Protection (2008) Derivation of Numerical Sediment Quality Guidelines for Florida Coastal Waters Using the Weight of Evidence Approach. Florida Sediment Quality Assessment (SQAGS), Volume 1, Chapter 5

42. Jernelov A, Landner $L$, Larsson $T$ (1975) Swedish perspectives on mercury pollution. J Water Pollut Control Fed 47(4):810-822

43. StatSoft (1999) STATISTICA for windows, Computer Programme Manual: Tulsa, OK

44. Mohiuddin KM, Ogawa Y, Zakir HM, Otomo K, Shikazono N (2011) Heavy metals contamination in water and sediments of an urban river in a developing country. Int J Environ Sci Technol 8(4):723

45. Mito S, Sohrin Y, Norisuye K, Matsui M, Hasegawa H, Maruo M, Tsuchiya M, Kawashima M (2004) The budget of dissolved trace metals in Lake Biwa, Japan. Limnology 5:7

46. Morillo J, Usero J, Gracia I (2004) Heavy metal distribution in marine sediments from the southwest coast of Spain. Chemosphere 55:431

47. O'sullivan A, Wicke D, Cochrane T (2012) Heavy metal contamination in an urban stream fed by contaminated air-conditioning and stormwater discharges. Environ Sci Pollut Res 19(3):903

48. Sekabira K, Oryem Origa H, Basamba TA, Mutumba G, Kakudidi E (2010) Assessment of heavy metal pollution in the urban stream sediments and its tributaries. Int J Environ Sci Technol 7(3):435

49. Giesy JP, Solomon KR, Coates JR, Dixon KR, Giddings JM, Kenaga EE (1999) Chlorpyrifos: ecological risk assessment in North American aquatic environments. Rev Environ Contam Toxicol 160:1-129

50. Barak NAE, Mason CF (1989) Heavy metal in water, sediment, and invertebrates from rivers in eastern England. Chemosphere 19(10/11):1709-1714

51. Pandey J, Singh R (2015) Heavy metals in sediments of Ganga River: upand downstream urban influences. Appl Water Sci 1

52. United State Environmental Protection Agemcy (USEPA) (1989) Risk assessment guidance for superfund. In: Human Health Evaluation Manual Part A, Interim Final, vol. I. United States Environmental Protection Agency, Washington (DC). 1989 EPA/540/1-89/002

53. Cardwell RD, Brancato MS, Toll J, DeForest D, Tear L (1999) Aquatic ecological risks posed by tributyltin in United States surface waters: pre-1989 to 1996

54. Pradit S, Wattayakorn G, Angsupanich S, Baeyens W, Leermakers M (2010) Distribution of trace elements in sediments and biota of Songkhla Lake, southern Thailand. Water Air Soil Pollut 206(1):155

55. Loska K, Wiechuła D (2003) Application of principal component analysis for the estimation of the source of heavy metal contamination in surface sediments from the Rybnik Reservoir. Chemosphere 51:723 
56. Anderson RV, Vinikour WS, Brower JE (1978) The distribution of Cd, Cu, $\mathrm{Pb}$, and $\mathrm{Zn}$ in the biota of two freshwater sites with different trace metal inputs. Holarct Ecol 13:377-384

57. Zarei I, Pourkhabbaz A, Khuzestani RB (2014) An assessment of metal contamination risk in sediments of Hara Biosphere Reserve, southern Iran with a focus on the application of pollution indicators. Environ Monit Assess 186:6047

58. Adekola FA, Eletta OAA (2007) A study of heavy metal pollution of Asa River, llorin. Nigeria; trace metal monitoring and geochemistry. Environ Monit Assess 125: 157

59. Adomako D, Nyarko BJB, Dampare SB, Srfor-Armah Y (2008) Determination of toxic elements in waters and sediments from River Subin in the Ashanti Region of Ghana. Environ Monit Assess 141(1-3):165-175

60. Chien LC, Hung TC, Choang KY, Yeh CY, Meng PJ, Shieh MJ, Han BC (2002) Daily intake of TBT, $\mathrm{Cu}, \mathrm{Zn}, \mathrm{Cd}$, and As for fishermen in Taiwan. Sci Total Environ 285:177-185

61. Fu J, Zhao C, Luo Y, Liu C, Kyzas GZ, Luo Y, Zhao D, An S, Zhu H (2014) Heavy metals in surface sediments of the Jialu River, China: Their relations to environmental factors. J Hazard Mater 270:102

62. Karbassi AR, Monavari SM, Nabi Bidhendi GR, Nouri J, Nematpour K (2008) Metal pollution assessment of sediment and water in the Shur River. Environ Monit Assess 147(1-3):107

63. Islam MS, Ahmed MK, Raknuzzaman M, Habibullah-Al-Mamun M, Islam MK (2015) Heavy metal pollution in surface water and sediment: a preliminary assessment of an urban river in a developing country. Ecol Indic 48:282

64. Gupta SK, Chabukdhara M, Kumar P, Singh J, Bux F (2014) Evaluation of the ecological risk of metal contamination in river Gomti, India: a biomonitoring approach. Ecotoxicol Environ Saf 110:49

65. Kwon YT, Lee CW, Ahn BY (2001) Sedimentation pattern and sediment bioavailability in a wastewater discharging area by sequential metal analysis. Microchem J 68:135

66. Chai L, Li H, Yang Z, Min X, Liao Q, Liu Y, Men S, Yan Y, Xu J (2017) Heavy metals and metalloids in the surface sediments of the Xiangjiang River, Hunan, China: distribution, contamination, and ecological risk assessment. Environ Sci Pollut Res 24:874-885

67. Jiang D, Wang Y, Zhou S, Long Z, Liao Q, Yang J, Fan J (2019) Multivariate analyses and human health assessments of heavy metals for surface water quality in the Xiangjiang River Basin, China. Environ Toxicol Chem 38:1645-1657

68. Mao L, Mo D, Guo Y, Fu Q, Yang J, Jia Y (2013) Multivariate analysis of heavy metals in surface sediments from lower reaches of the Xiangjiang River, southern China. Environ Earth Sci 69:765-771

69. Zhu J, Zhang J, Li Q, Han T, Xie J, Hu Y, Chai L (2013) Phylogenetic analysis of bacterial community composition in sediment contaminated with multiple heavy metals from the Xiangjiang River in China. Mar Pollut Bull 70:134-139

70. Protano C, Zinnà L, Giampaoli S, Spica VR, Chiavarini S, Vitali M (2014) Heavy metal pollution and potential ecological risks in rivers: a case study from Southern Italy. Bull Environ Contam Toxicol 92:7

71. Devanesan E, Suresh Gandhi M, Selvapandiyan M, Senthilkumar G, Ravisankar R (2017) Heavy metal and potential ecological risk assessment in sediment collected from Poombuhar to Karaikal Coast of Tamilnadu using Energy-dispersive X-ray fluorescence (EDXRF) technique. Beni-Suef Univ J Basic Appl Sci 6:285-292

\section{Publisher's Note}

Springer Nature remains neutral with regard to jurisdictional claims in published maps and institutional affiliations. 